\title{
Telling Stories of Violence in Adult ESL Classrooms: Disrupting Safe Spaces
}

\section{Monica Waterhouse}

This article develops a complex understanding of safe space in relation to adult refugee learners' oral literacy practice of telling stories of violent life experiences in English as a second language (ESL) classrooms. A rhizoanalytic approach brings theoretical and empirical elements into conversation to ask two questions. Can the exigencies of safe classroom spaces accommodate the telling/hearing of violent stories? What might be the pedagogical potential of such storytelling in ESL classrooms? Grounded in literature critiquing safe space discourses and theoretical work that views the telling of violent stories as ambivalent (destructive and productive), I argue that unproblematic conceptualizations of safe classrooms become impossible when refugees are involved. I present a data assemblage drawn from a qualitative study with two ESL teachers and four students. In a series of interview vignettes, the students describe their experiences of hearing their classmates' stories of violence, highlighting the emotional impact of these experiences and their capacity to bring on new ways of thinking. This analysis reframes refugee storytellers as powerful, agentive forces in the ESL classroom and suggests that sharing stories is pedagogical in the sense that it affects and transforms learners. In closing, I discuss the practical and ethical implications of the research.

Cet article développe une interprétation complexe du concept d'espace sûr relatif à une pratique littéraire orale selon laquelle des réfugiés adultes racontent des expériences de vie violentes dans leurs cours d'anglais langue seconde (ALS). Une approche "rhizoanalytique » réunit en conversation des éléments théoriques et empiriques pour poser deux questions: 1- Est-il possible de raconter et d'écouter des récits violents tout en respectant les exigences liées aux espaces surs en classe? et 2- Quel pourrait être le potentiel pédagogique de ces récits dans les cours d'ALS? Puisant dans la recherche qui critique le discours relatif aux espaces surs et dans le travail théorique qui perçoit comme ambivalent (destructif et productif) le fait de raconter des histoires violentes, j'affirme qu'il n'est pas possible de concevoir des espaces surs en classe qui ne posent aucun problème lorsque les élèves sont des réfugiés. Je présente des données tirées d'une étude qualitative impliquant deux enseignants d'ALS et quatre élèves. Par le biais d'une série de capsules d'entrevues, les élèves décrivent ce qu'ils ressentent en écoutant les récits de violence que racontent leurs camarades de classe et soulignent l'impact émotionnel de ces expériences et leur capacité d'entrainer de nouveaux modes de réflexion. Cette analyse restructure les conteurs réfugiés comme des forces puissantes et capables dans les cours d'ALS et propose que le partage de récits est 
pédagogique dans le sens qu'il exerce une influence sur les apprenants et les transforme. Je discute des conséquences pratiques et éthiques de cette recherche.

KEY WORDS: adult ESL, newcomers, violence, affect, transformative pedagogy

"I work hard to create a classroom where people feel safe."

"This classroom is supposed to be a welcoming, warm, comfortable, safe environment for students to learn in."

These comments were made by two English as a second language (ESL) teachers who participated in the research reported in this article. Their comments encapsulate its central concern, that is, to develop a more complex understanding of safe space. More specifically, it explores how safety is understood in adult immigrant language classrooms where refugee learners may choose to tell stories of violent life experiences. This research draws on data from a larger study (Waterhouse, 2011), which examined how experiences of peace, and as a corollary various forms of violence, play into everyday classroom life in the Language Instruction for Newcomers to Canada (LINC) program. LINC is a federally funded ESL program serving adult immigrants with permanent resident or convention refugee status. Significantly the study showed that there is much more going on in LINC than the program's primary mandate of English language instruction might suppose. Learning in this context is not limited to learning language, but encompasses new understandings about oneself, one's social worlds, and one's place in those worlds.

In this article I focus on questions prompted by selected data from the study involving the oral literacy practice of telling stories in the LINC classroom, more particularly stories of violence told by newcomers escaping conflict in their countries of origin. The sharing of these violent stories in LINC classrooms and their impact on the students who heard them prompts several important questions: What exactly is a safe classroom and does it necessarily exclude all forms of violence, including the secondary violence of telling/hearing violent stories? What might be the transformative and pedagogical potential of recounting violent experiences in the LINC classrooms? My primary objective is to respond to these questions by considering existing conceptualizations and critiques of safe space in the literature and by theoretically framing violence in ways that account for its ambivalent character (both destructive and productive). This more complex theoretical lens is applied to practice through classroom-based data from LINC students who have experienced their classmates' telling of stories of violence.

It is essential to stress from the outset that by posing questions about the pedagogical potential of telling stories of violence, I am in no way promoting a teaching approach that involves asking students to share their violent 
life experiences. I avoid using the noun pedagogy because I do not encourage teachers to implement violent storytelling as a teaching tool. I exclusively use the adjective pedagogical to emphasize the educational potential inherent in the practice of storytelling when it happens in classrooms, unbidden by the teacher and often beyond the teacher's control. I am not calling teachers to adopt a new teaching method. However, I am inviting reflection on classroom responses to stories of violence that, as I argue below, inevitably arise when working with refugee learners.

In the first part of the article I describe the study including the research context, the qualitative data collection methods used, the ethical considerations inherent in the research design, and how rhizoanalysis as a dynamic theory-practice enabled the selection and interconnection of the interview vignettes that are presented later in the data assemblage section. I then review literature germane to questions of violence in ESL and literacy educational contexts to demonstrate that it tends to be preoccupied with how to meet the unique learning needs of refugees and victims of trauma in classrooms. Though understandable, this pedagogical preoccupation means that little attention is given to how the telling of stories of violence by these learners can reframe refugee storytellers as powerful, agentive forces in the classroom, rather than victims. This leads into a discussion of dominant discourses about safe space in the ESL literature in order to critique taken-for-granted assumptions about safe space and to assert that unproblematic conceptualizations of safe space become impossible when refugees with life histories of violence are involved. I highlight the ambivalent nature of safe spaces and extend this notion into the next section where violence is also theorized as ambivalent, having both destructive and productive forms. I contrast existing theoretical framings of violence in language and literacy research literature with my use of Deleuzian concepts and Multiple Literacies Theory (Masny, 2009b) to reframe the telling of stories of violence by refugee students in LINC as pedagogical-affecting and transforming their classmates. The next section, the data assemblage, brings this theorizing into conversation with practice through interviews with three LINC students who heard stories of violence in their classrooms. Finally, in the two closing sections, I discuss the practical implications of the research, situated within the current sociopolitical climate, which call teachers to adopt an ethical orientation toward what might be called pedagogical violence.

\section{A Rhizoanalytic Study in LINC}

\section{Methods and Ethical Considerations}

The setting for the study was a multisite LINC program delivered by an Ontario-based service provider. Participants were recruited in LINC Level 4 and 5 classrooms on the basis that the curriculum guidelines for these levels 
seemed most likely to produce fruitful connections to the specific foci of this study and that the student participants would be more likely to have sufficient language proficiency to express their ideas in English. One Level 4 teacher and one Level 5 teacher volunteered to participate. Of the students who volunteered to participate in each of these two classes, two were selected based on advice from their teacher about the likelihood that they would be present in class regularly and that they would continue in the program for the duration of the onsite research activities.

All participant names used in this article are self-selected pseudonyms that were chosen during the informed consent process. Given the sensitive nature of the research topic, an important ethical consideration was the possibility that participants might experience negative emotions and other forms of discomfort as a result of reflecting in LINC on their experiences (e.g., potential experiences of vicarious trauma or retraumatization). To mitigate this risk, counselling services provided by a local immigrant support organization were made available to the participants. Notably, to the best of my knowledge, no participant availed themselves of these services.

Over a four-month period, the two teachers and four of their adult ESL students participated in qualitative inquiry strategies including video-recorded classroom observations, corresponding individual interviews, and the collection of classroom artifacts. The students were also invited to keep audio journals. The study comprised a total of 12 observation sessions, six in each class. Relevant classroom artifacts from the activities observed were also collected (e.g., worksheets, newspaper articles). These data sources were considered supporting materials that served as entry points for discussion during the subsequent interviews.

The primary data sources were audio-recorded, open-ended individual interviews with each student and teacher participant. Interviews usually took place the day after the video-recorded observation sessions and lasted approximately one hour. There were three scheduled interviews with each participant, but two of the student participants, Tuzi and Maria, requested a fourth interview because they had experiences at LINC that they wanted to share and that they felt were relevant to the study.

Each interview had three main components. (a) After the first interview, I began each interview by following up on various issues arising from earlier conversations (i.e., clarifications, elaborations, etc.). (b) The participant and I viewed and discussed clips I had selected from the most recent in-class observational video. We considered how the event shown in each clip might be important, how it contributed to language and literacy learning, and what thoughts were prompted as we viewed each clip. (c) The final component of each interview involved addressing discussion topics I had prepared in advance and which were derived from the theoretical framework informing the study. These topics covered 
- basic biographical information about participants (Interview 1);

- what the words literacy and literacies meant to participants (Interviews 1 and 3);

- how participants perceived the LINC mandate to orient newcomers to the Canadian way of life and what connections the mandate might have to peace and violence (Interview 2);

- experiences in LINC that prompted some sort of change in participants (Interviews 1, 2 and 3); and

- experiences of peace and violence arising in LINC (Interview 3).

From an ethical standpoint, it is important to emphasize that participants were never directly asked to disclose personal stories of violence; rather, the focus of our discussions was on the happenings in the LINC classroom. However, because the students were aware of the focus of the study, many times discussions of peace and violence and related life experiences arose through our open-ended discussions around the classroom observational video. It was not until the final scheduled interview that I explicitly invited participants' comments using the following guiding questions:

- Do experiences of violence (overt or covert, such as social injustice) and/ or talk of violence-related issues find their way into the classroom? If so, how? (Curriculum, students' experiences, teacher's lessons, what kind of literacy activities?)

- Do experiences of peace and/or talk of peace-related issues find their way into the classroom? If so, how? (Curriculum, students' experiences, teacher's lessons, what kind of literacy activities?)

\section{Analysis: Onto-epistemology and Practice}

What I have described so far are well-established qualitative data-gathering methods; however, the approach to analysis, commensurate with the Deleuzian onto-epistemological underpinnings of the study, may be less familiar. This rhizoanalytic approach (Masny, 2013) views data as transgressive; analysis as a creative, process producing connections; and reporting as mapping different linkages. Data selected from the larger study are chosen "according to their power to act and intervene rather than to be interpreted" (Colebrook, 2002 , p. xliv). This selection is a form of experimentation rather than interpretation, "a dynamic and open-ended process in which [one] work[s] with the constitutive rhizomatic elements of the assemblage to create something new from it" (Nordstrom, 2015, p. 171). Rather than revealing a pre-existing reality and fixing a representation of that reality, "the data assemblage creates a contingent organization-a making, remaking, and unmaking of the constitutive data" (Nordstrom, 2015, p. 170) in relation to theory. Nordstrom (2015) elaborates how a data assemblage works: the data creates a map, while the researcher serves "as a mediator who works within the map so that it 
can continue to compose, associate, and transform" (p. 179). In this respect a rhizoanalysis is never finished, as the data assemblage ceaselessly shifts and functions differently with each rereading of the data, with each new reader, with each new encounter with theory.

In practice, rhizoanalysis is a continual and iterative activity that began as soon as I visited the first LINC site. I constantly made notes in a research journal, especially as I watched each video and listened to each interview before the next meeting with a participant. Later, as I transcribed each interview, treating data sources for each participant as a cluster, I highlighted excerpts that stood out as "interesting, remarkable, or important" (Deleuze \& Guattari, $1991 / 1994$, p. 82) in relation to the research focus on peace and violence. This process was not about setting up categories, but about tracking responses to reading data-texts and thoughts that were happening. As I read and reread interview transcripts I wrote side notes about connections that were beginning to form between the data and the theoretical framework, between different elements of the data, and so forth. I began mapping my thinking using mindmapping software to create and continually revise diagrams of connections that were happening, creating new assemblages of elements from within the data to see how they might work. These mappings moved me into the reporting phase of the research process wherein the results are presented as data assemblages of interconnected vignettes, theory, concepts, and ideas.

One of these data assemblages, reported as a series of interview excerpts below, coalesced around the teachers' ideas of safe space, LINC students' experiences of hearing classmates' stories of violence, and theoretical framings of violence and transformation. Thus rhizoanalysis brings theory and practice together as a "system of relays in an assemblage, in a multiplicity of bits and pieces both theoretical and practical" (Deleuze, 2004, p. 207). Over the course of our interviews three of the four student participants talked about their experiences of hearing stories of violence as told by their LINC classmates who were likely refugees. Notably, these three research participants-Tuzi, Maria, and Isabel - were not refugees. For various personal reasons, all three had chosen to immigrate to Canada. However, the influence of violence in LINC classrooms can, as this research shows, extend beyond those who experienced it firsthand.

\section{Refugees, Violence, and Trauma in Language and Literacy Classrooms}

Refugee students in ESL classrooms face "hidden barriers to learning stemming from the effects of trauma" (Bobrow Finn, 2010, p. 587). Thus teachers need to be aware of these effects, and Isserlis (2000) proposes that one way to "make the classroom safer for all" (p. 3) is to allow students' "concerns about violence to surface in one form or another" (p. 3). One possible way these 
concerns may come to the fore is through narratives of violence and trauma. Although there should never be any obligation to tell stories of violence, ESL students may still take the initiative to bring up such personal narratives and may wish to discuss highly emotional issues (Bobrow Finn, 2010; Dumas, 2008). Bobrow Finn (2010) warns that ESL teachers may not be prepared for the consequences of these narratives shared in their classrooms, yet at the same time, Dumas (2008) underscores the importance of allowing a place for these stories in terms of validating students' experiences and identities. The three authors cited here, in their discussion of the role of traumatic narratives in adult ESL education, primarily focus on how best to support and teach students who have experienced violence or trauma. Issues regarding the responses of others in the classroom when a story of violence is shared are mentioned in passing only. In this article I turn attention to what happens to non-refugee classmates as they listen to stories of violence. This question is especially relevant in LINC, where refugees and immigrants regularly study side-by-side. Moreover, it foregrounds the agentive powers of the refugee storyteller in LINC classrooms.

\section{The (Im)possibility of Newcomer Language Classrooms as Safe Spaces}

Horsman's (1999) in-depth study of the multifaceted impact of violence in Canadian language and literacy educational contexts noted literacy workers' "sense of responsibility for creating a safe classroom" (p. 122). Similarly, the ESL research literature, particularly with respect to working with refugees and other victims of violence, is replete with discourses that emphasize safe as an essential characteristic for the classroom, such as "the ESL teacher ... is in the unique position of being able to provide a safe environment" (Dumas, 2008, p. 7); "the establishment of a safe classroom environment" (Bobrow Finn, 2010, p. 592); "the classroom as a safe and predictable place is key to building community among and safety for learners" (Isserlis, 2000, p. 4); "build a classroom community that provides a safe space for students" (Adkins \& Harper, 2001, p. 2). Many of the ESL teachers working with war refugees who participated in Magro's (2006/2007) study "commented on the importance of creating a 'safe haven' where students felt valued and included" (p. 73). Another pertinent example is Baynham's (2006) study of adult English language classes for refugees and asylum seekers in the United Kingdom, which found that some teachers "actively worked to insulate the classroom interaction from the vicissitudes of these external pressures [such as racism and poverty], creating a safe space for students, a respite from pressure" (p. 38).

However, in spite of such apparently laudable efforts on the part of teachers, three disruptions point to the impossibility of providing newcomers with a safe space for language learning. First, despite ESL teachers' efforts to maintain a safe space for their students, including those with refugee status, inevi- 
tably the kinds of external pressures described by Baynham (2006) encroach on classrooms. Research reported by Bettencourt (2001) documents the wide range of violences faced by Canadian newcomers (e.g., poverty, police harassment, racism and discrimination, and traumatic premigration experiences such as genocide). Baynham (2006) also points to the inevitability of such violent experiences intruding into the language classroom and shows how the urgency of refugees' life experiences in particular, often experiences of violence (e.g., racism, poverty, homelessness), create conditions that "bring the outside in" (p. 25) and produce messier, but more dynamic, agentive, and contingent pedagogical spaces. In contrast to framings of newcomers as marginalized and disempowered, he views these encroachments of life into the classroom "in terms of the agency of student protagonists, who interrupt the orderliness of classroom discourse to bring the outside in and the contingency of teacher responses to such 'interruptive' moments in the classroom discourse" (p. 25). Thus it is of primary importance to attend to how issues of violence arising in the newcomer language classrooms are addressed and how these responses may enable more empowered positionings for refugee students. Moreover, there is a clearly identified need to respond more effectively to such issues in Canadian adult language learning programs such as LINC (Ali, 2004; Khalideen, 1998; Magro, 2006/2007).

The second argument for the impossibility of providing newcomers with a safe space for language learning derives from critiques of safe space discourse, a discourse that tends to articulate safe space as something to be defined and provided by the teacher. Notice how the locus of responsibility for furnishing the safe space is firmly situated with the teacher in Dumas's (2008) call to address homophobia and heterosexism in ESL classrooms. She writes: "The ESL teacher ... is in the unique position of being able to provide a safe environment for queer people" (p. 7; emphasis added). According to Dumas, the teacher can accomplish this task by carefully evaluating her teaching materials, by "actively providing a safe, open space for learners who might want to bring [queer issues] up" (p. 8), and by being "equipped with follow-up questions that allow for multiple perspectives" (p. 8). Thus, while a certain amount of agency is accorded the learners who "bring up issues," it remains the teacher who "actively provides," "is equipped," and "allows." Notably, this same teacher-centred assumption with respect to safe ESL classroom spaces are echoed in the discourse examples presented at the beginning of this section; it is the teacher who builds community to establish or create safe space.

On the one hand, I unequivocally support Dumas's essential point that ESL classrooms are sites where the complexities of learner identities at the intersection of linguistic, cultural, and sexual diversity cannot be ignored. On the other hand, turning to established critiques of safe space discourse, I question the positioning of the teacher as the primary driver in the creation of a safe space. Because safe space "is always contested and ambiguous dis- 
cursive terrain" (Stengel \& Weems, 2010, p. 507), it becomes necessary to question the teacher practice of defining safety on behalf of students (Barrett, 2010). For example, teachers and students expressed competing views regarding what is considered violent and unsafe content in classroom discussions in both Horsman's (2005) study of the impacts of trauma on women's literacy learning in Nova Scotia and in Baynham's (2006) study of ESL classes for refugees and asylum seekers. As an alternative to teacher-defined safe spaces, Horsman (2001) advocates for devoting the time necessary to engage in participatory practices to collaboratively define spaces that are considered safe for everyone. Baynham (2006) signals a similar participatory approach in the ESL context by proposing a move "from the notion of the authoritative teacher permissively creating space ... towards one where the classroom is a site of dynamic pushes and pulls, with teacher and student agendas robustly shaping interaction, claiming space" (p. 38).

The third and final disruption of safe space speaks to its ambivalence. In Hodkinson's (2015) analysis of safe space as a prevalent and taken-forgranted educational concept, he underscores the duality and ambivalence of safety such that it can characterize that which protects, but also that which causes harm. He thus concludes that "safety is situation and culturally specific and is time located" (p. 153). Horsman (1999) also reveals the complicatedness of the concept of safety, describing the impact of classroom disclosures about violent experiences.

Some learners will want the program to be a safe place to tell their stories, others will want it to be a place safe from hearing disturbing stories. ... Many literacy workers talked about the challenge of creating a safe space in their program. (p. 121)

Similarly, in second language classrooms, tensions may be created when refugee students feel secure enough that they decide to share their stories; however, their teachers and classmates are unprepared to hear them. These stories are at best discomfiting and at worst can result in vicarious trauma for the listeners (Horsman, 1999). For these reasons I caution teachers against asking for the telling of personal stories of violence as a teaching strategy, while at the same time recognizing that refugee learners often take the initiative to share their stories.

In sum, the impossibility of newcomer language classrooms as unproblematic safe spaces is underscored by the inevitability of intrusions of violence into language classrooms serving immigrant and refugee groups coupled with critiques of teacher-defined safe space discourses and recognition of the ambivalence of such spaces. Dislodging and complicating the notion of safe space has important implications for rethinking violence in relation to literacy and language classrooms in adult education contexts, particularly those serving refugee students. Joining the challenge to break the silence around experiences of violence in pedagogical conversations, Horsman (2005) pro- 
vocatively asks, "What is learned through violence?" (p. 291), that is, what may be the pedagogical possibilities of addressing issues of violence? The data I present in the data assemblage section below offer a response to this question through the classroom literacy practice of oral storytelling in LINC.

\section{(Re)thinking Violence, Literacy, and Transformation}

Various theoretical frameworks have been used to study violence in relation to literacy and second language education. For example, Horsman's (1999) influential study of the impacts of violence on women's literacy learning takes a critical stance to interrogate societal norms underpinning violence and to effect broad social change, while Duckworth's (2014) social justice-oriented study draws on Bourdieu's notion of symbolic violence to analyze the gender and social class inequality experienced by adult basic skills learners. In contrast to the critical theory paradigms used in these studies, I have opted for a poststructural framing through the work of Gilles Deleuze in order to account for the ambivalent nature of both safe spaces (as identified in the literature reviewed above) and violence.

A Deleuzian conceptualization of violence offers a way to think beyond the critiques of safe space discourse, to acknowledge the ambivalent nature of violence as both destructive and productive, and to reframe the telling of stories of violence by refugee students in LINC as potentially transformative and pedagogical. To begin this (re)thinking of violence, consider violence in the common, received view which is generally equated with harm. This harmful form of violence is understood as encompassing actions causing overt damage (e.g., physical injury, psychological trauma, and destruction) as well as violences that operate by more covert systemic means (e.g., poverty, inequality, discrimination, oppression). Moreover, the received view of violence implies a binary opposition between violence and nonviolence. While this binary conceptualization enables educational institutions to offer much needed support to students (including refugees) suffering the effects of violent trauma, it can, at the same time, place constraints on the scope of what is thinkable.

While publicly speaking out against the ubiquitous terrors of violence in the received view (see, for example, Deleuze, 2006), Deleuze also conceptualizes violence differently, in a way that blurs the received binary between violence-nonviolence. Through Deleuze (1968/1994) we can think about two kinds of violence (p. 53). He aligns one kind of violence with the oppression of "the politician" which stifles that which differs, and with harm in the received view. It is a force of destruction. However, the other kind of violence aligns with revolutionary "poets" whose violence is understood not as harm, but rather as a productive disruption, what Deleuze calls a deterritorialization, that may be our best hope against the first kind of violence. I assert that the refugee who decides to become a storyteller in LINC classrooms 
may be viewed as enacting the violence of the poet as a "creative power" ( $\mathrm{p}$. 53) aligned with life's power to disrupt existing stabilities, for example a socalled safe classroom, in order to introduce difference and make possible the creation of something new. It is this productive potential to open the way for transformations - new learning - that makes the violence of the poet pedagogical in language classrooms.

The concept of transformation taken up in my analysis derives from Deleuze's notions of affect and becoming as realized within Multiple Literacies Theory (MLT) (Masny, 2009b). This understanding of transformation is distinct from others predominating in adult learning contexts where transformative learning is generally defined as "dramatic, fundamental change in the way we see ourselves and the world in which we live" (Merriam, Caffarella, \& Baumgartner, 2007, p. 130). More precisely, in psychological conceptualizations, the focus is primarily on learning that brings about developmental changes in an individual learner. However, for many in language and literacy education who work within critical frameworks, the emphasis is equally on changing society and its underlying structures that perpetuate diverse forms of violence (Horsman, 1999). Transformative learning in the field of language and literacy is also frequently grounded in Paulo Freire's emancipatory educational philosophy and aims at empowering learners and achieving societal change leading to social justice outcomes. Duckworth (2014), for example, asserts that even when learners have been victims of violence, "adult literacy education can often be a critical space to support and empower learners to take agency, no matter what their trajectory so far" (p. 20), an assertion that also has important implications for refugee students in LINC who may opt to share their stories.

The dichotomy between psychological theories of individual transformation and critical theories of social transformation is a limitation that can, I argue, be resolved through Deleuze's relational concept of affect. According to Deleuze (1978), each body has its own unique affects: powers to affect and be affected. This could be a human body (i.e., a refugee in LINC) or an abstract nonhuman body (i.e, an oral text, a story). When two (or more) bodies meet they are transformed as a result of coming into an affective relationship with each other. Significantly, the outcomes of these transformations, or becomings as Deleuze calls them, cannot be defined in advance; they may be joyous for some bodies and destructive for others. The transformative, affective powers associated with reading, writing, speaking, and listening in second language classrooms are theoretically captured by MLT (Masny, 2009b). It theorizes literacies as affective processes involving oral, visual, written, tactile, and digital texts; thus, a refugee's oral storytelling is a text. Reading, broadly understood, is a sense-event in which student-bodies, teacherbodies, text-bodies, and social-bodies are transformed in unpredictable ways through their relational encounters with each other. Sense is what happens as an effect of such encounters and shapes the reader in relation to experiences 
in life. Thus "through reading, reading the world, and self as texts, literacies constitute ways of becoming with the world" (Masny, 2009a, p. 14) simultaneously individual and social.

\section{Data Assemblage}

This particular assemblage was produced in response to the problem of the ambivalence of safe spaces and the question: What might be the transformative potential of the oral literacy practice of telling stories of violence in LINC? Both teachers who participated in the research echoed taken-for-granted discourses of safe spaces noted in the literature. Sara, the Level 4 classroom teacher, emphasized her efforts in this respect, saying, "I work hard to create a classroom where people feel safe," while Brooke, the Level 5 classroom teacher, described her classroom as follows: "This classroom is supposed to be a welcoming, warm, comfortable, safe environment for students to learn in." Like many language teachers working with newcomers, Sara and Brooke care deeply for their students and they assume responsibility for not only supporting their students' language acquisition, but also for assuring their successful settlement in their new country and their general well-being. It is little wonder that they place great importance on creating a safe classroom for their students. Yet despite these teachers' efforts to establish and maintain a safe space for their students, various forms of violence invaded their LINC classrooms. Brooke and Sara explained how their students have, of their own volition, disclosed postmigration experiences of racism, poverty and home eviction, and domestic abuse as documented in earlier research (Baynham, 2006; Bettencourt, 2001). In addition, the students participating in the research-Tuzi, Maria, and Isabel-mentioned how premigration experiences of violence were also recounted in their LINC classrooms. I propose to examine these moments in terms of their transformative potential, the violence of the poet, by focusing on the affective power of refugee students sharing their personal life experiences of violence prior to arriving in Canada.

A common activity involving an oral literacy practice in LINC is to talk generally about their personal experiences. During the study, this telling of stories sometimes happened spontaneously between students. At other times this practice was encouraged by the teachers through learner-centred activities they taught around issues relevant to the students' lives. Such personally meaningful topics inspired students to share aspects of their everyday life in Canada: stories about work, school, shopping, hobbies, personal interests, and so forth. However, the teachers' LINC lessons also included topics recommended in the literature, such as family (Bobrow Finn, 2010), country of origin (Goggins, 2004), and experiences of resettlement (Magro, 2006/2007). These recommendations come with the caveat that such topics may be sources of learner discomfort in light of past experiences of violence (Isserlis, 2000) and must be carefully considered given their potential to re- 
traumatize students who, for example, may have lost family members (Goggins, 2004). Indeed, because some LINC students arrive in Canada as refugees from regions of conflict, recounting stories often involves describing various experiences of violence (as harm in the received conceptualization). This is why, once again, I do not advocate that teachers aim to have refugee students share their personal stories of violence, but I do advocate for the importance of critically reflecting on what transpires when such stories inadvertently arise in the classroom.

\section{Tuzi's Response to Hearing a Story of Violence}

Tuzi, a student in the LINC Level 5 classroom, had arrived in Canada 12 months earlier and had been studying in LINC most of that time. She talked about her experience of hearing a classmate's story of violence. To understand the context of Tuzi's interview comments below, it is important to know that, from the outset, the research participants were aware of my research focus on how experiences of peace and violence manifested themselves in the LINC classroom. I was upfront about the fact that the project stemmed from a personal experience I had had while working in a different LINC site several years earlier which I recounted to them as follows.

One day I was discussing the Canada Food Guide with a LINC conversation group when one of the students commented that she didn't eat red meat. When I asked if she was a vegetarian, I was shocked to hear her explain that red meat brings back difficult memories of witnessing her husband's murder. At the time, I was stunned that such connections could happen from an innocuous discussion about the Canada Food Guide.

During one of our interviews, Tuzi and I were reviewing the focus of the study, and I reminded Tuzi of my personal story. In response, Tuzi offered her own oral text about a Serbian classmate whose father and brother had been killed in ethnic and religious conflicts.

Tuzi: Oh - In my classmate - I remembered. Not my - My classmate, a student who came from $\mathrm{Se}-\mathrm{Se}-\mathrm{Serbia}$. She told us - Oh, she cried. She told us. Let me think what we talked - what was we talking - some topics. She told us that her brother - her brother and father be killed during the - not the civil war. Just the two groups in her country. The two groups, different religion, different religions. And one day somebody came to their home and took her brother away and then he never came back. That's why she immigrated here. They told us that.

Monica: And she told that because of an activity you were doing?

Tuzi: Yes, yes. I forgot what activities. Maybe we read some newspapers and mention some topics she told us. 
Monica: So what was that like for you to hear her story?

Tuzi: Because I heard that story. Not focus - not on the one person. We know this event because we learn some news and read some newspapers in China. We- I know what happened in the world. We know that [unintelligible]. Like Rwanda, and several-. We know this. Or we heard that a lot, a lot of people died. But we don't know what - how it's happened. She told us her brother, her father- Just they came to their home and take her brother. So easy. No reason. [pause]

Monica: How did that affect you?

Tuzi: At that time I felt very lucky. Oh I live in a peaceful country. Oh I feel so luck. And so upset about her.

Tuzi's comments suggest that if students with histories of violence opt to share their life stories in LINC, it can produce an especially affectively powerful oral text. Understood through the lens of MLT (Masny, 2009b), the oral stories are texts and the telling/reading of such stories are sense-events, vectors through which the deterritorializing, affective forces of becoming (Deleuzian violence) are released. Tuzi reflects: "I feel so luck. And so upset."

While affective readings may actualize as feelings, they are, more fundamentally, variations in our very existence, such that the emotional response is indicative of a shift (Deleuze, 1978). In other words the emotional response indicates something has happened to Tuzi; there has been some kind of transformation as an effect of reading her classmate's oral story-text, although MLT maintains that we cannot know in advance what the quality of this transformation will be. There is the risk that such becomings actualize as vicarious trauma, for example. There is the chance that Tuzi's feeling of being lucky will not be unpacked any further. However, there is also the potential for this emotional response to become a pathway to "enter a relation of affective equivalence" (Anwaruddin, 2016, p. 391) that enables a deeper understanding of the suffering of others and, potentially, a more ethical response to it. For Anwaruddin (2016), affective equivalence is a fundamental principle of Critical Affective Literacy that moves beyond critical theory's exclusive reliance on rationalism and validates emotional ways of knowing. In this light, it becomes important for critical educators to be aware of the relational and affective engagements happening in their classroom, like the one described by Tuzi, and to seriously consider what is learned through that process about language, but also about oneself and one's world. 


\section{Maria's Response to Hearing a Story of Violence}

Maria, Tuzi's classmate, had also been studying in LINC for 12 months, though she and her family emigrated from Mexico two and a half years earlier. During one interview Maria commented that her son learns good values at his Canadian school, and so I asked her about her own experiences in LINC. This line of conversation led Maria to describe how her classmates' and neighbour's oral literacy practice of telling life stories involving violence (in the received view as harm) affected her.

Monica: So do you think there are any ways that you learn values in LINC?

Maria: Yes because um - [pause] You have to respect another person and you learn a lot about other - other cultures. And sometimesFor example, I'm not going to complain about the violence in Mexico anymore because it's not a very - safety city. But also it's not violent as I have - hear from other people from other country. They really have a violence because they are fighting in Middle East. You can lost the life to the bomb and it's a very stressful time.

Monica: Some of the other students talk about this?

Maria: Yes! Yes. My - So, I say OK, I'm not too bad with that because- For example, my neighbour from Iran she told me that they decide to came to Canada because when Iran had problems with Iraq there was a bomb explode very close to his house. And I say, "Oh my goodness!" Why did you came to Canada? I say, "It doesn't matter." [laughs shyly]

\section{Monica: Doesn't matter?}

Maria: Yes, because I decide to come to Canada because I think it's the best for my children.

Although Maria describes a conversation with her neighbour, she also indicates that she has heard similar stories from classmates in her LINC classroom. Maria's response to the story of bombing in Iran evokes surprise, even shock: "Oh my goodness!" she exclaims. Dufresne (2006) observes that such affective responses can be indicative of deterritorializations happening through literacies and learning. Reading produces a deterritorialization; Maria notices how different her reasons for coming to Canada are as compared with her neighbour. As sense emerges through reading and reading the world, difference is encountered, violence too. How might this sense-event actualize the violence of the poet by sending a worldview into disorder? How will a reterritorialization occur? How might Maria's worldview reorganize differently? MLT views the sense of the bombing story not in terms of mean- 
ing or interpretation, but rather as productive, that is, readers are shaped, or transformed, by their investment in reading.

\section{Isabel's Response to Hearing a Story of Violence}

Four months before I met her, Isabel had moved from Cuba to join her new Canadian husband, and for three months she had been studying in the LINC Level 4 classroom. As Isabel and I wrapped up our interview on this occasion, I invited any final comments she might have wanted to add. She took the opportunity to share the following experience.

Isabel: I remember one time. [Sara] give us an activity to write an experience. It was. She want talk about two or three minutes each in front of the group. Talk about one exciting activity that you do. Probably a trip in another town or another place or the trip that you go, that you did when you go come to Canada. And everybody give her own topic. And there were some experience really, really impressed from people from Africa for example. And it make you know everybody feel sad if his story was sad. Happy when his story was happy. And it was really, really nice.

Monica: Can you give me an example of one of those stories that you remember?

Isabel: Probably I can tell you all because sometimes it was a very nice topic. But I can't forget the way that [my classmate]... She talk about her trip to Canada and how was with her children and his husband, her husband (sorry). How she get the airport, how was in the airport with the immigrant. It was really quite interesting. Because we were working in the part of the airport where you get the, the room to start to wait and [pause] it was sad sometimes. It was exciting another one. You know.

Monica: Did it, did that story, um, cause you to reflect on your own experience in some way?

Isabel: For sure. For sure.

Monica: Can you tell me more about that?

Isabel: When you see people that are- that are really bad experience in their life. People she loves, her child. Because another women kill her child, two month old. And I, in Cuba I never think. People talk about guns. People talk about drugs. I know that this exists. I know that violence can exist.... Violence. Sure of course. There are people [unintelligible]. But never, never see a people with those problems. I can't imagine. I say well, probably I'm bad because I'm afraid. I'm alone without my daughter. But never [pause]. She is safe. She is fine. I never think that kind of thing can happen in the real. For me 
it was like a film.... It's not the same. For example me: OK, if I want to move I'm not dying here in Cuba. I go because I love my husband and I have to [pause] want a real life, a normal life. Like uh, but not because I was in problem; dangerous.

Monica: Right, right.

Isabel: It's totally different.

An English language lesson, involving writing and telling stories of personal life experiences, led to the disclosure of one newcomer's story of violence. The telling of stories is a sense-event that allowed (received) violence-the murder of an infant-to enter the LINC classroom. Hearing the story of a child's murder, reading that oral text, prompted connections with Isabel's own experiences as a mother. When Isabel decided to come to Canada, she came without her young daughter in order to be sure that Canada would be a good place to raise her child first. In the meantime her daughter was being cared for by Isabel's mother in Cuba. As her mothering experiences connect with the experience of listening to her classmate's story, sense produces new affects and Isabel says: "Probably I'm bad because I'm afraid. I'm alone without my daughter," and yet she feels her daughter is safe. What kind of reading of self is going on in response to the story of violence told by her classmate? Could this constitute a foundation of affective equivalence on which to build towards Critical Affective Literacy (Anwaruddin, 2016)?

When events in life and literacies' engagements in LINC present experiences that are far from our own understanding of how the world works-perhaps so far outside our worldview that "it was like a film," as Isabel expresses it -it may create a rupture. When such a deterritorialization of a worldview occurs (Deleuzian violence), how will a reterritorialization take place? As Isabel concludes, "It's totally different," and it is difference that produces becoming, thereby transforming the individual in unforeseen ways.

\section{Transformative and Pedagogical Potential of Violent Stories}

In the closing sections of this article I consider some implications that flow from more complicated theoretical understandings of violence and safe space, and from the insights gleaned through the research data about the telling of violent stories by refugee students in LINC. I first address implications for learning in LINC and then turn to issues related to the ethical stakes of teaching.

Following Bogue's (2004) theorizing of learning via Deleuze, it is the capacity of encounters with difference to disrupt and transform, as in the case of telling stories of violence in LINC, which I consider pedagogical. Importantly, it is not the teacher that is responsible for initiating this kind of pedagogical encounter by asking for stories of violence. Rather when learners 
offer a story, then "to learn is ... to undergo the disorienting jolt of something new, different, truly other" (Bogue, 2004, p. 341). Bogue explains: "By 'learning' Deleuze clearly does not mean the mere acquisition of any new skill or bit of information, but instead the accession to a new way of perceiving and understanding the world" (p. 328). Therefore learning, from this viewpoint, impacts how sense may actualize in future reading events. For example, in her audio journal Isabel spoke about watching the 2006 movie Blood Diamond, set in the context of civil war in Sierra Leone. An affective, relational reading of this audio-visual text produced links to Isabel's classmate and her classmate's violent life experiences. Sense goes beyond what a text means to create a becoming. Affects were released and actualized as emotions; in explaining the experience of viewing Blood Diamond Isabel commented, "I FEEL horrible. I CRIED all the time" and "[the movie] made me think how different in our country we live and how different are the reasons when you move to a new country." Reading texts relationally-juxtaposing a refugee's oral story of her child's murder with a popular film-prompts a pedagogical encounter with difference opening the way for new learning and a new worldview.

Of course, telling/reading stories of violence (received view) may go on without any apparent disruption in the classroom; a territory may be maintained. But the reading can also go off in unexpected directions, releasing affects, deterritorializing forces (Deleuzian violence). This also creates possibilities for critical affective engagements (Anwaruddin, 2016) that, in turn, present the ethical exigency for teachers to reflect on their responses to violence. Such a pedagogical space can, admittedly, be a difficult space: upsetting, uncomfortable. Yet, at the same time it may also be a space of becoming, where the power to affect and be affected provides opportunities for transformations as a reterritorialization takes place. I read this as the actualization of the refugee storyteller's agency and pedagogical power. While there are no guarantees in terms of how these transformations will actualize, there is always the potential that they may create more fruitful ways of living together than have been previously thought of.

Isabel, Tuzi, and Maria described how they were powerfully affected by hearing about their classmates' experiences of violence: the murder of a baby, ethnic conflict, and bombings. These stories shocked and upset them, throwing them out of their comfort zone. However, this may also be, at the same time, a productive disruption, the violence of the poet, which opens the way for transformative learning. This tension once again underscores the ambivalence of safe spaces such that "experiencing discomfort should not be confused with the absence of safety" (Zembylas, 2015, p. 165). In the wake of these storytelling encounters with refugee classmates, these LINC students began to rethink their own perceptions of violence and safety in relation to their country of origin and to Canada. What might be learned in the process about oral language, but also about how we might live together in more 
life-affirming ways? I pose this question while at the same time recognizing the uncertain potential of such risky classroom storytelling events and the ambiguous feelings associated with them. "The specific directionality and outcomes of these emotional, psychosocial, and intellectual events are unplanned, unshared, and/or unrecognizable in the 'real time' of the physical encounter" (Stengel \& Weems, 2010, p. 506), meaning that Deleuzian affective learning remains unabashedly undetermined. The great epistemological mystery of affects is that we do not know exactly how learning will go, what the affects will produce. Will the outcomes feel joyous or destructive? This indeterminacy presents an ethical tension.

\section{Toward an Ethics of Pedagogical Violence}

It is the transformative and pedagogical potential of telling stories that leads Horsman $(1999,2005)$ to call for educators in adult language and literacy contexts to give serious consideration to the diverse impacts of violence in their classrooms. Such a pedagogical conversation may feel risky, but what more is risked by maintaining a territory, by denying difference, denying the affective? Horsman (1999) fears that "too much caution on the part of instructors can lead to so much anxiety about learners' sensitivities that everyone might be silenced" (p. 117). Then, how might silencing issues of violence also stifle potentially life-affirming becomings?

Policy driving Canada's immigrant language programs tends to myopically focus on "human capital models, the functional goal of job preparation, and individualized skills" (Guo, 2013, p. 37). While these have clear social import, they elide other essential ethical questions about learners' life experiences and the transformative effects of literacies and language learning. Such questions are pressing, given Canada's ongoing reliance on immigration as a major driver of population growth and given the number of these newcomers that arrive as refugees under the Protected Persons immigration category. In 2011, protected persons accounted for $11.2 \%$ of all immigrants admitted, a level reflective of the average over the previous decade (Chagnon, 2013). Even as I write these words, communities across Canada are facilitating the settlement of 25,000 Syrian refugees whose entry was fast-tracked by the newly elected Liberal government in late 2015. Yet at the same time fear and anti-immigrant sentiment is growing as an effect of recent terrorismidentified attacks (e.g., October 22, 2014 in Ottawa; November 13, 2015 in Paris; March 22, 2016 in Brussels; July 14, 2016 in Nice) operating as what Massumi (2010) calls "excess-threat-generating" events (p. 60), which then justify the rightness of pre-emptive political action in the face of a felt future threat (e.g., World War II-era Japanese internment camps or exclusionary immigration policies today). In times like these, accounting for violence, in its destructive and productive forms, is perhaps the most salient issue facing educators working with newcomers. 
Within the data assemblage-involving storytellers, audiences, teachers, students, theory, readers - two conceptual movements circulate and intertwine. One involves received conceptualizations of violence, where violence is seen as harm (overt and covert). The other movement maps violence differently, a Deleuzian conceptualization where violence is seen as a vital force of disruption that opens the way for newness to flow, for becoming, and even for potentially more fruitful ways of living to emerge. It is in these senses that storytelling becomes potentially pedagogical and transformative. This productive violence of the poet, involving de/reterritorializations, disruptions and transformations, is often accompanied by uncomfortable and upsetting affective forces. As Zembylas (2015) observes, this discomfort "entails a particular ethic and a turbulent ground on which to critique deeply held assumptions about ourselves and others" (p. 166). Such actualizations of affective forces require that educators "learn to cope within the economy of violence" (Tenenbaum, 2000, p. 375) that takes account of the complex intersections of violence in the received view as harm and violence in the Deleuzian sense as disruption as well as the complicated ambivalence of safe spaces. This economy of pedagogical violence weighs the harm that students may suffer (received view) as a result of affective disruptions (Deleuzian violence) against the necessity of confronting oppression, harm, and violence in the world (received view) and affirming difference (Deleuzian violence). Thus ESL teachers of adult newcomers are called to confront the (im)possibility of a safe classroom and find themselves responsible to map a new ethics of violence (Tenenbaum, 2000; Zembylas, 2015) as they walk with their students along an uncertain line in between destruction and disruption.

\section{Acknowledgements}

I gratefully acknowledge the funding provided by the Social Sciences and Humanities Research Council in support of this research. I also express my thanks to the teachers and students for their participation in the research and for welcoming me into their classrooms.

\section{The Author}

Monica Waterhouse is an Assistant Professor in the Département de Langues, linguistiques et traduction, Université Laval, where she teaches courses in research methodology and second language pedagogy. Her current research explores the social and curricular stakes of language education in newcomer language programs through the lens of Deleuzian affect theory.

\section{References}

Adkins, M. A., \& Harper, E. (2001). Tips for teachers during times of trauma (ERIC digest). Retrieved from ERIC database (ED456678).

Ali, N. Z. (2004). Meaning making for South Asian immigrant women in Canada (Unpublished doctoral dissertation). University of Toronto, Toronto, ON. Retrieved from the Digital Dissertations database.

Anwaruddin, S. M. (2016). Why critical literacy should turn to "the affective turn": Making a case for critical affective literacy. Discourse: Studies in the Cultural Politics of Education, 37(3), 381-396. https://doi.org/10.1080/01596306.2015.1042429 
Barrett, B. J. (2010). Is "safety" dangerous? A critical examination of the classroom as safe space. Canadian Journal for the Scholarship of Teaching and Learning, 1(1), Article 9. https://doi. org/10.5206/cjsotl-rcacea.2010.1.9

Baynham, M. (2006). Agency and contingency in the language learning of refugees and asylum seekers. Linguistics and Education, 17(1), 24-39. https://doi.org/10.1016/j.linged.2006.08.008

Bettencourt, E. (2001). Recent research on newcomer youth. Contact, 27(2), 53-60.

Bobrow Finn, H. (2010). Overcoming barriers: Adult refugee trauma survivors in a learning community. TESOL Quarterly, 44(3), 586-596. https://doi.org/10.5054/tq.2010.232338

Bogue, R. (2004). Search, swim, and see: Deleuze's apprenticeship in signs and pedagogy of images. Educational Philosophy and Theory, 36(3), 327-342. https://doi.org/10.1111/j.14695812.2004.00071.x

Chagnon, J. (2013). Migration: International, 2010 and 2011 (Statistics Canada Catalogue no. 91-209-X). Ottawa, ON. Retrieved from http://www.statcan.gc.ca/pub/91-209-x/2013001/ article/11787-eng.pdf

Colebrook, C. (2002). Understanding Deleuze. Crows Nest, Australia: Allen \& Unwin.

Deleuze, G. (1978). Spinoza, Cours Vincennes 24/01/1978 [T. S. Murphy, Trans.]. In Les Cours de Gilles Deleuze. https://www.webdeleuze.com/textes/11

Deleuze, G. (1994). Difference and repetition (P. Patton, Trans.). New York, NY: Columbia University Press. (Original work published 1968)

Deleuze, G. (2004). Intellectuals and power: An interview with Michel Foucault (M. Taormina, Trans.). In D. Lapoujade (Ed.), Desert islands and other texts: 1953-1974 (pp. 206-213). Los Angeles, CA: Semiotext(e).

Deleuze, G. (2006). Two regimes of madness: Texts and interviews 1975-1995 (D. Lapoujade, Ed.; A. Hodges \& M. Taormina, Trans.). New York, NY: Semiotext(e).

Deleuze, G., \& Guattari, F. (1994). What is philosophy? (H. Tomlinson \& G. Burchell, Trans.). New York, NY: Columbia University Press. (Original work published 1991)

Duckworth, V. (2014). Learning trajectories, violence and empowerment amongst adult basic skills learners. Abingdon, UK: Routledge.

Dufresne, T. (2006). Exploring the processes in becoming biliterate: The roles of resistance to learning and affect. International Journal of Learning, 12(8), 347-354.

Dumas, J. (2008). The ESL classroom and the queerly shifting sands of learner identity. TESL Canada Journal/Revue TESL du Canada, 26(1), pp. 1-10. https://doi.org/10.18806/tesl.v26i1.387

Goggins, K. (2004).Too scared to learn: ESL teachers play key role in helping newcomers adjust. CrossCurrents-The Journal of Addiction and Mental Health, 8(1), 16. Retrieved from http:// go.galegroup. $\mathrm{com} / \mathrm{ps} / \mathrm{i} . \mathrm{do}$ ?id=GALE\%7CA123327711\&v=2.1\&u=crepuq_ulaval\&it=r\&p=CP I\&sw=w\&asid $=61554 a 48 b 4 f 03 c d 30 c e 79 c e c 0174 b c e c$

Guo, Y. (2013). Language policies and programs for adult immigrants in Canada: A critical analysis. Canadian Ethnic Studies/Études ethniques au Canada, 45 (1-2), 23-41. https://doi. org/10.1353/ces.2013.0022

Hodkinson, A. (2015). "Safe spaces" in education: Ghettos of marginalisation and dominance or places of equality and social justice? International Review of Qualitative Research, 8(2), 145-165. https://doi.org/10.1525/irqr.2015.8.2.145

Horsman, J. (1999). Too scared to learn: Women, violence, and education. Toronto, ON: McGilligan Books.

Horsman, J. (2001). "Why would they listen to me?" Reflections on learner leadership activities. In P. Campbell \& B. Burnaby (Eds.), Participatory practices in adult education (pp. 77-102). Mahwah, NJ: Lawrence Erlbaum.

Horsman, J. (2005). Creating change in literacy programs: Taking account of violence. In J. Anderson, T. Rogers, M. Kendrick, \& S. Smythe (Eds.), Portraits of literacy across families, communities, and schools: Intersections and tensions (pp. 277-300). Mahwah, NJ: Lawrence Erlbaum.

Isserlis, J. (2000). Trauma and the adult English language learner (ERIC digest). Retrieved from ERIC database (ED444397). Washington, DC: National Clearinghouse for ESL Literacy Education. 
Khalideen, R. (1998). LINC programs in Edmonton as adult education practice: Learners' perspectives (Unpublished doctoral dissertation). University of Alberta, Edmonton, AB.

Magro, K. (2006/2007). Overcoming the trauma of war: Literacy challenges of adult learners. Education Canada, 47(1), 70-74.

Masny, D. (2009a). Literacies as becoming: A child's conceptualizations of writing systems. In D. Masny \& D. R. Cole (Eds.), Multiple Literacies Theory: A Deleuzian perspective (pp. 13-30). Rotterdam, Netherlands: Sense Publishers.

Masny, D. (2009b). What's in a name?: Multiple Literacies Theory. In D. Masny \& D. R. Cole (Eds.), Multiple Literacies Theory: A Deleuzian perspective (pp. 181-192). Rotterdam, Netherlands: Sense Publishers.

Masny, D. (2013). Rhizoanalytic pathways in qualitative research. Qualitative Inquiry, 19(5), 339-348. https://doi.org/10.1177/1077800413479559

Massumi, B. (2010). The future birth of the affective fact: The political ontology of threat. In M. Gregg \& G. J. Seigworth (Eds.), The affect theory reader (pp. 52-70). Durham, NC: Duke University Press.

Merriam, S. B, Caffarella, R. S., \& Baumgartner, L. M. (2007). Learning in adulthood: A comprehensive guide (3rd ed.). San Francisco, CA: Jossey-Bass.

Nordstrom, S. N. (2015). A data assemblage. International Review of Qualitative Research, 8(2), 166-193. https://doi.org/10.1525/irqr.2015.8.2.166

Stengel, B. S., \& Weems, L. (2010). Questioning safe space: An introduction. Studies in Philosophy and Education, 29(6), 505-507. https://doi.org/10.1007/s11217-010-9205-8

Tenenbaum, A. (2000). Anti-human responsibilities for a postmodern educator. Studies in Philosophy and Education, 19(5), 369-385. https://doi.org/10.1023/A:1005258925854

Waterhouse, M. C. (2011). Experiences of multiple literacies and peace: A rhizoanalysis of becoming in immigrant language classrooms (Unpublished doctoral dissertation). University of Ottawa, Ottawa, ON. http://hdl.handle.net/10393/19942

Zembylas, M. (2015). "Pedagogy of discomfort" and its ethical implications: The tensions of ethical violence in social justice education. Ethics and Education, 10(2), 163-174. https://doi.org/1 $0.1080 / 17449642.2015 .1039274$ 